\title{
Teaching Followership in Leadership Education
}

\author{
Deana M. Raffo \\ Assistant Professor of Management \\ Department of Management and Marketing \\ Middle Tennessee State University \\ Murfreesboro, TN \\ deana.raffo@mtsu.edu
}

\begin{abstract}
This paper provides leadership educators with a resource for teaching followership. It presents a lesson for teaching students about followership in contemporary society by including key concepts and follower characteristics followed by class activities and assignments designed to engage students in active learning and self-reflective processes. A dose of whimsy enhances this lesson with the use of a YouTube video that eloquently and humorously illustrates the crucial role followers play in organizational life.
\end{abstract}

\section{Introduction}

This paper provides leadership educators with a resource for teaching followership that includes key concepts and class activities. This lesson is enhanced with a humorous YouTube video that describes the role of today's follower as being crucial. While the term followership started being used in conjunction with the term leadership to recognize the important role of the follower (Kelley, 1992), only mere mention is made of followership in leadership textbooks. While followership is gaining momentum in the leadership literature (Baker, 2007), it is still mistakenly undervalued by society as a whole (Kellerman, 2008).

Followership is a concept that is often undervalued, thought to be inconsequential or just common sense as it lingers in the shadow of leadership (Kellerman, 2008). Historically, leadership studies have neglected or limited their focus on follower styles, competencies, and attributes (Collinson, 2006) where theorists and researches have focused on leadership almost to the exclusion of examining followership, even though most people are followers most of the time. The leadership literature is vast, yet some scholars have argued that we cannot fully understand leadership without also understanding the significance, characteristics, 
and complexities of followership (Bass, 2008; Popper, 2011; Van Vugt, Hogan, \& Kaiser, 2008).

Since most of us are more often followers than leaders and even engage in multiple follower roles at any given time, followership should be more prevalent in our research (Chaleff, 2009; Kelley, 1988). I argue it should be in our teaching. As Kelley (1998) stated concerning the pressures of today's organizational life:

$[\mathrm{N}]$ ow demands that we all learn how and when we most effectively advance our self-interest by following... which starts with abandoning a positional reference to the issue of who are followers, who leads.... (since) performance challenges - not position - should determine when you should follow and when you should lead (p. 204).

However, following provides a complex dilemma because our society incorrectly stereotypes followers in a condescending manner as docile, passive, obedient, conformists, indifferent, weak, dependent, unthinking, failures, and helpless (Baker, 2007; Chaleff, 2009; Collinson, 2006; Kellerman, 2008; Rost, 1993).

In the United States following is often even considered an insult because we have such an aversion to these characteristics which are actually incorrect perceptions about what effective followership is all about (Kellerman, 2008). Our students bring these misconceptions with them to the classroom. Nevertheless, we can argue that by fully understanding the principles of followership, students can better understand leadership (Komives, Lucas, \& McMahon, 2007). After all, as Kellerman (2008) wrote "better followers beget better leaders" (p. xxii).

Harris, Bruce, and Jones (2011) examined the leading academic and popular texts used by leadership educators. In their survey of 33 leadership educators, they identified 12 academic and 21 popular texts. Only one of those texts included a chapter on followership (Leadership Theory, Application \& Skill Development by Lussier and Achua), but it was used by only $2.3 \%$ of the respondents. Only one popular press book was identified (by one survey respondent) that had a follower focus (Courageous Follower by Chaleff).

Since leadership textbooks pay so little attention to followership, this paper strives to remedy the current state of affairs by providing leadership educators with a resource for teaching followership in contemporary society. It includes a theoretical base of followership and summary of key concepts and follower characteristics as influenced by followership theory. It is followed by class activities and assignments designed to engage students in active learning and selfreflective processes. A dose of whimsy is included by enhancing this lesson with a YouTube video that eloquently and humorously illustrates the crucial role followers play in organizational life. 


\section{Lesson Overview \& Lesson Plan}

The following lesson plan is designed to facilitate learning with the primary intent to introduce students to followership in contemporary society. It includes key concepts and characteristics as well discussion questions, class activities, and selfreflective assignments and can serve as a stand-alone lesson. The primary learning objective for this lesson is that the students will identity and explain followership concepts and characteristics in contemporary society.

The assignments are certainly not exhaustive, but are intended to offer a variety of methods, exercises, and assignments to facilitate student learning. The works from Chaleff, Kellerman, and Kelley were paramount in preparing this lesson.

Before the lecture portion of the class where the theoretical construct and key concepts are taught, I have found it helpful to pose the following discussion questions to the class or small groups first. These questions typically get responses that adhere to conventional wisdom about followers including that they are passive and dependent, or at the very least they are less important than leaders.

- What comes to mind when you think of followers (or followership)?

- Are these terms generally used in a positive or negative sense?

- What characteristics are traditionally associated with followers?

I have found this discussion provides a helpful segue into then sharing major followership themes and debunking the myths about followers to then foster a paradigm shift to the post-industrial paradigm perspective of followership.

\section{Theoretical Base and Key Concepts}

The lesson continues with the theoretical construct of followership with the major themes, key points, and follower characteristics. The following points from the literature (Baker, 2007; Chaleff, 2009; Hackman \& Johnson, 2009; Kellerman, 2008; Kelley, 1988; Rost, 1993; Smith, 1997) provide an explanation of the major followership themes and follower characteristics that can help students to understand followership from post-industrial paradigm perspective with a focus (see Table 1):

- The term followership honors and recognizes the importance of the role of the follower.

- Followers and leaders are roles that can be exchanged. Most people play the roles of both follower and leader within an organization and the reality is that most of us are more often followers than leaders. 
- Followers are active rather than passive. They can and should initiate change and engage in problem-solving and ethical behavior.

- Leaders and followers share a common purpose. They may have different functions or roles, but they are both equally committed to the organization, share responsibility for meeting organizational goals, and should both strive for organizational excellence.

- There is an interconnection between follower and leader. They are interdependent, a two-way influence process, in a partnership, and reciprocal. Much of a leader's success depends on effective followers and both roles deserve equal weight.

- Leaders are no longer equated with supervisors; therefore, followers should no longer be equated with subordinates.

- Effective followership prepares one to be an effective leader.

- Leaders and followers are "two sides of one process, two parts of a whole" (Chaleff, 2009, p. 2).

- According to Kelley (1998), follower roles are determined by levels of activity and critical thinking. There are 5 roles - sheep, yes people, alienated followers, survivors, and effective followers.

- Follower characteristics have traditionally been seen as dependent, indifferent, detached, passive, unthinking, and amoral. These characteristics represent the industrial paradigm.

- In contrast, from the post-industrial paradigm, follower characteristics include self-management, team spirit, positive attitude, contributor, competent, and ethical.

Table 1 summarizes the key characteristics that contrast the industrial versus postindustrial paradigms from a variety of sources (Baker, 2007; Chaleff, 2009; Hackman \& Johnson, 2009; Kellerman, 2008; Kelley, 1988; Rost, 1993; Smith, 1997). Faculty may use this as a reference for lecture notes, PowerPoint slides, and student handouts. 
Table 1.

Follower Characteristics from the Industrial and Post-industrial Paradigms

\begin{tabular}{lll}
\hline Industrial & Post-industrial & Post-industrial Paradigm \\
Paradigm & Paradigm & Descriptions \\
Characteristics & Characteristics &
\end{tabular}

\begin{tabular}{|c|c|c|}
\hline Dependent & Self-management & $\begin{array}{l}\text { self-reliant, thinks for self, can work well without } \\
\text { close supervision, responsible, self-starter, well- } \\
\text { balanced, takes initiative, self-control, self- } \\
\text { reflective, clarifies role and expectations, seeks } \\
\text { honest feedback }\end{array}$ \\
\hline Indifferent & Team Spirit & $\begin{array}{l}\text { appreciates goals and needs of the team, loyal, } \\
\text { loyal, sees coworkers as colleagues rather than } \\
\text { competitors, contributing "sweat equity" to the } \\
\text { performance of others, offers support to the leader, } \\
\text { works as partners with the leader, builds bridges }\end{array}$ \\
\hline Detached & Positive Attitude & enthusiastic, appreciative, gracious, optimistic \\
\hline Passive & Contributor & $\begin{array}{l}\text { functions well in change environment, believes } \\
\text { he/she can offer as much value to the organization } \\
\text { as the leaders do, committed to a } \\
\text { cause/idea/organization, search for overlooked } \\
\text { problems, raises issues or concerns when } \\
\text { necessary }\end{array}$ \\
\hline Unthinking & Competent & $\begin{array}{l}\text { master skills useful to the organization, high } \\
\text { performance standards, committed to professional } \\
\text { development, good judge of personal strengths } \\
\text { and weaknesses, thinks independently and } \\
\text { critically, problem solver, insightful, talented, } \\
\text { skilled, curious, innovative }\end{array}$ \\
\hline Amoral & Ethical & $\begin{array}{l}\text { honest, courageous, credible, considers integrity of } \\
\text { paramount importance, good judgment, admits } \\
\text { mistakes, stands up for beliefs, knows oneself, } \\
\text { resists inappropriate influence of the leader, makes } \\
\text { right ethical decisions }\end{array}$ \\
\hline
\end{tabular}

Sources: Baker, 2007; Chaleff, 2009; Hackman \& Johnson, 2009; Kellerman, 2008; Kelley, 1988; Rost, 1993; Smith, 1997

Once the key concepts are presented, I show a YouTube video entitled Leadership Lessons and the Dancing Guy (Sivers, 2010). The video is of a lone dancer who 
then gets the crowd to join him. The scene and narration provides a humorous learning tool to further stimulate students' thinking about followership from the post-industrial paradigm.

Using video in various formats, including YouTube, allows us to illustrate a concept or principle while making class content more relatable to students. Berk (2009) cites more than a dozen studies that support using video or film to support student learning. By the same token, multimedia allows leadership educators to teach leadership theory in new and inventive ways that captures students' attention, provides a catalyst for thoughtful discussion (Graham, Sincoff, Baker, \& Ackerman, 2003), and generates dialogue to drive home difficult or complex points (Williams, 2006).

Likewise, there are also benefits to using humor in teaching. It helps students engage in the learning process by creating a positive environment to allow students to better focus to the information being presented. Research shows that students who have teachers who use humor in the classroom tend to learn more since it aids recall (Garner, 2009). As such, the Leadership Lessons and the Dancing Guy video, using multimedia and humor, enhances the lesson to assist students with making the paradigm shift to understand the importance of followership.

After the lecture and showing the video, students should have a firm foundation to then commence with further class discussion, small group discussions, activities, and guided reflections and suggestions are provided as follows.

\section{Class Discussion Questions, Activities, and Self-Reflective Assignments}

\section{Class Discussion Questions (or Online Discussion Questions)}

- In the video, what is some of the terminology the narrator uses that shows that he recognizes the importance of the "followership?"

- In the video, the narrator says that the leader embraces the first follower as an equal. Remember a time when you embraced as an equal or felt empowered as a follower. What caused you to feel this way? What role does the leader play in empowering followers?

- In the video, the narrator says that new followers emulate followers - not the leaders? Do you agree or disagree?

- In the video, the narrator says that leadership is over-glorified. Do you agree or disagree? 
- What's it like to be a follower in a situation/organization/context with traditional (industrial) mindset of followership? How is it the same or different from a context with a post-industrial mindset of followership?

- Have your thoughts on followers changed from today's lesson? How? Are there ideas about followership that warrant more thought?

\section{Class Activities}

- Joseph Rost (1993), author of Leadership for the Twenty-first Century, says that we shouldn't use the term "followership" because followers engage in the "leadership" process, not the followership process. On the other hand, some say that the term "followership" best describes what followers do and how they differ from leaders. Debate the term "followership." Do followers participate in leadership as Rost advocates or do they engage in followership?

- The video narrator says that being a first follower is an under-appreciated form of leadership. Debate this notion. Is the "first follower" a form of leadership or is it followership?

- The video narrator, as well as Chaleff (2009), says that being a follower takes courage. In small groups, come up with real-life situations either personal or public where this is the case and share with the class.

\section{Self-Reflective Assignments (Journaling or Self-Reflective Paper)}

- What type of follower are you according to Kelley's (1998) follower types? How do you assess yourself as a follower? Do you tend to fit the characteristics of an industrial paradigm follower or a post-industrial paradigm follower? What are your followership strengths and shortcomings?

- Develop a personal action plan which describes actions you can take to be a more effective follower. Explain how this can also translate to effective leadership.

\section{Conclusion}

In conclusion, the term followers has been attributed with negative qualities, such as passivity, dependence, and detachment (Chaleff, 2009; Kellerman, 2008). As products of our society, I believe our students will largely continue to ascribe many of these characteristics to followers rather than viewing following as a positive and necessary part of the leadership process unless we teach them otherwise.

I teach this lesson about two-thirds of the way through the class once students have an understanding of leadership theories such as leadership traits, skills, styles. My student responses to including followership as a topic in a leadership 
class have been positive overall. Some of the typical types of comments that illustrate their learning are as follows:

- My thoughts on followers have changed. They have changed because now I clearly understand that it takes just as much work to be an effective follower as it does with an effective leader.

- Prior to studying the term "followership" my definition of a follower was a person who mimicked the actions of the leader, who did not have a mind of their own and had no leadership type traits. I was shocked when I found out my thoughts were totally wrong.

- Before studying this unit I never thought of followers as an important part of leadership but now I see that you cannot have effective leaders without effective followers and how much responsibility falls on followers as well.

- I really liked the second video about the young man dancing, not only was it entertaining but the video did an excellent job of explaining that leadership is the product of successful followership.

- The video clip of "leadership (and followers) lessons" shows how important that the first follower is to the leader. The first follower needs acceptance and praise from the leader. It's not just the leader that attracts other followers, followers need to see that the followers before them are cared for and are needed.

- This writing got me to think about the fact that we do spend so much time studying leadership, but not followership. It's like growing up learning how to be an effective speaker, but never an effective listener.

I believe we have an obligation to help our students get past an elitist view of leadership that coincides with a conformist view of followership. Once again, Rost (1991) challenges our thinking by saying that only people who are active in the leadership process should be considered followers because passive people are not in a relationship, or contributing to this process since they have chosen to not be involved. In other words, passive people are not followers. He goes so far as to say that "followers do not do followership, they do leadership" (p. 109). They are two sides of the same coin - leaders and followers are engaged in leadership together.

Just as Huber (2002) wrote that as leadership educators we must develop the capacity of individuals and organizations to lead, I believe an important part of 
that educational process is to also teach them how to effectively follow and to view followership in a positive light. As leadership educators, we can help our students reconceptualize how they view followers and nudge them past the preconceived notion that followers are unimportant and inconsequential to organizational success (Komives, Lucas, \& McMahon, 2007). Hence, we can facilitate an understanding of the conceptual framework of followership and the value of followers, and foster an appreciation of the critical contributions followers make to organizational life. 


\section{References}

Baker, S. D. (2007). Followership: The theoretical foundation of a contemporary construct. Journal of Leadership \& Organizational Studies, 14(1), 50-60.

Bass, B. M. (2008). The Bass handbook of leadership ( $4^{\text {th }}$ ed.). New York: Free Press.

Berk, R. A. (2009). Multimedia teaching with video clips: TV, movies, YouTube, and MtvU in the college classroom. International Journal of Technology in Teaching and Learning, 5(1), 1-21.

Chaleff, I. (2009). The courageous follower ( $3^{\text {rd }}$ ed.). San Francisco: BerrettKoehler.

Collinson, D. (2006). Rethinking followership: A post-structuralist analysis of follower identities, The Leadership Quarterly, 2, 179-189.

Garner, R. L. (2009). Humor in pedagogy: How ha-ha can lead to aha! College Teaching, 54(1), 177-180.

Graham, S. T., Sincoff, M. Z., Baker, B., \& Ackerman, J. C. (2003). Reel leadership: Hollywood takes the leadership challenge. Journal of Leadership Education, 2(2), 37-45.

Hackman, M. Z., \& Johnson, C. E. (2009). Leadership: A communication perspective $\left(5^{\text {th }} \mathrm{ed}\right.$.). Long Glove, IL: Waveland Press.

Harris, J., Bruce, J., \& Jones, D. (2011). You are what you read: Inside leadership texts. Journal of Leadership Education, 10(1), 23-40.

Huber, N. S. (2002). Approaching leadership education in the new millennium. Journal of Leadership Education, 1(1), 25-34.

Kellerman, B. (2008). Followership: How followers are creating change and changing leaders. Boston: Harvard Business Press.

Kelley, R. E. (1988). In praise of followers. Harvard Business Review, 66(6), 142-148.

Kelley, R. E. (1992). The power of followership: How to create leaders people 
want to follow and followers who lead themselves. New York: Currency/Doubleday.

Komives, S. R., Lucas, N., \& McMahon, T. R. (2007). Exploring leadership: For college students who want to make a difference ( $2^{\text {nd }}$ ed.). San Francisco: John Wiley \& Sons.

Popper, M. (2011). Toward a theory of followership. Review of General Psychology, 15(1), 29-36.

Rost, J. C. (1993). Leadership for the twenty-first century. Westport, CT: Greenwood Publishing.

Sivers, D. (2010, February 10). First follower: Leadership lessons from dancing guy. Retrieved from http://www.youtube.com/watch?v=fW8amMCVAJQ

Smith, D. K. (1997). The following part of leading. In F. Hesselbein, M. Goldsmith, \& R. Beckhard (Eds.) The leader of the Future: New visions, strategies, and practices for the next era (pp. 199-207). San Francisco: Jossey-Bass.

Van Vugt, M., Hogan, R., \& Kaiser, R. B. (2008). Leadership, followership, and evolution, American Psychologist, 63(3), 182-196.

Williams, J. (2006). Pirates and power: What Captain Jack Sparrow, his friends, and his foes can teach us about power bases. Journal of Leadership Education, 5(2), 60-68. 


\section{Author Biography}

Deana M. Raffo, Ed.D., serves as Assistant Professor of Management in the Department of Management and Marketing at Middle Tennessee State University. She teaches the core leadership courses in MTSU's Leadership Studies minor. Dr. Raffo is the recipient of the 2009 Outstanding Program by the Association of Leadership Education. Her primary research interests include leadership education and leadership and reflection. 